\title{
MICRONUTRIENT ACCUMULATION IN CONILON COFFEE BERRIES WITH DIFFERENT MATURATION CYCLES
}

\author{
Wellington Braida Marré(1,2), Fábio Luiz Partelli ${ }^{(1) *}$, Marcelo Curitiba Espindula ${ }^{(3)}$, Jairo \\ Rafael Machado Dias ${ }^{(4)}$, Ivoney Gontijo ${ }^{(1)}$ and Henrique Duarte Vieira ${ }^{(5)}$
}

(1) Universidade Federal do Espírito Santo, São Mateus, Espírito Santo, Brasil.

${ }^{(2)}$ Instituto Capixaba de Pesquisa, Assistência Técnica e Extensão Rural, Nova Venécia, Espírito Santo, Brasil.

(3) Empresa Brasileira de Pesquisa Agropecuária, Embrapa Rondônia, Porto Velho, Rondônia, Brasil.

(4) Universidade Federal de Rondônia, Departamento de Agronomia, Rolim de Moura, Rondônia, Brasil.

(5) Universidade Estadual do Norte Fluminense Darcy Ribeiro, Centro de Ciências e Tecnologias Agropecuárias, Campos dos Goytacazes, Rio de Janeiro, Brasil.

${ }^{*}$ Corresponding author.

E-mail: partelli@yahoo.com.br

\begin{abstract}
The number of days between anthesis and maturation of conilon coffee berries varies according to the genotype. Thus, it is believed that periods of greater nutrient demand for fruit formation also vary according to the genotype, directly influencing fertilizer management. The goal of this study was to establish accumulation curves for the micronutrients boron, copper, iron, manganese, and zinc in conilon coffee trees with different maturation cycles. The experiment was conducted in Nova Venécia, State of Espírito Santo, Brazil, during the reproductive cycle of the 2010/2011 crop year. Four coffee genotypes with different maturation cycles (early, intermediate, late, and super-late) were studied. A completely randomized experimental design was used with five replications. The treatments correspond to the accumulation of $\mathrm{B}, \mathrm{Cu}, \mathrm{Fe}, \mathrm{Mn}$, and $\mathrm{Zn}$ in the berries every 28 days in the period from flowering to harvest. The early, intermediate, and late genotypes accumulated $\mathrm{Fe}, \mathrm{Cu}$, and Mn in a similar manner, with sigmoid curves, whereas the super-late genotype accumulated these nutrients exponentially. Zn was accumulated by all four genotypes following a sigmoid curve. The early, intermediate, and late genotypes accumulated B linearly, whereas the super-late genotype accumulated $B$ following a sigmoid curve. The maturation cycle of the genotype must be taken into account to apply the correct rate of micronutrient fertilization in coffee plantations.
\end{abstract}

Keywords: Coffea canephora, genotypes, fertilizer management. 


\title{
RESUMO: ACÚMULO DE MICRONUTRIENTES EM FRUTOS DE CAFEEIROS 'CONILON' COM DISTINTOS CICLOS DE MATURAÇÃO
}

\begin{abstract}
O número de dias compreendido entre a antese e a maturação dos frutos de cafeeiros conilon varia em razão do genótipo utilizado. Desse modo, acredita-se que os períodos de maior demanda nutricional para formação dos frutos também variam por causa dos genótipos, influenciando diretamente o manejo da adubação. Nesse sentido, objetivou-se estabelecer curvas de acúmulo para boro, cobre, ferro, manganês e zinco em frutos de cafeeiros conilon com distintos ciclos de maturação. O experimento foi conduzido no município de Nova Venécia, Espírito Santo, durante o ciclo reprodutivo do ano agrícola 2010/2011. Foram utilizados quatro genótipos de cafeeiros com ciclos de maturação diferenciados (precoce, intermediário, tardio e supertardio). O delineamento experimental foi inteiramente casualizado com cinco repetições. Os tratamentos correspondem ao acúmulo de $\mathrm{B}, \mathrm{Cu}, \mathrm{Fe}, \mathrm{Mn}$ e $\mathrm{Zn}$ nos frutos, a cada 28 dias no período compreendido entre a floração e a colheita. Os genótipos precoce, intermediário e tardio acumulam Fe, $\mathrm{Cu}$ e Mn de maneira semelhante, com curvas sigmoidais, enquanto o genótipo supertardio acumula esses nutrientes de maneira exponencial. O Zn é acumulado de forma sigmoidal por todos os genótipos estudados. Os genótipos precoce, intermediário e tardio acumulam $B$ de forma linear enquanto o genótipo supertardio, de forma sigmoidal. O ciclo de maturação do genótipo deve ser levado em consideração para o correto parcelamento da adubação de micronutrientes na lavoura cafeeira.
\end{abstract}

Palavras-chave: Coffea canephora, genótipos, manejo da adubação.

\section{INTRODUCTION}

More than 120 species have been described for the Coffea genus; however, only C. arabica, C. canephora, and C. liberica are commercially cultivated (Davis et al., 2011). C. arabica (arabica coffee tree) stands out as the main commercial crop, but the cultivation of $C$. canephora (robusta or conilon coffee tree) has significantly contributed to an increase in global coffee production (Conab, 2013).

The conilon coffee tree is characterized by reproduction through allogamy. Using asexual propagation is necessary to obtain productive varieties with a well-defined maturation cycle (Bragança et al., 2001). These varieties are polyclonal, consisting of sets of genotypes that are usually grouped according to their maturation cycles, which vary from early to super-late (Fonseca et al., 2004).

Knowing the maturation periods of coffee berries is essential for agricultural planning and to predict harvest yield, quality, and commercialization (Bardin-Camparotto et al., 2012). There have been important studies of gene expression at different stages of fruit development (Budzinski et al., 2011). The variation attributed to the fruit maturation cycle is related to the climate conditions for cultivation and/or the coffee genotype being used (Pezzopane et al., 2003; Petek et al., 2009).

Although varieties are formed by grouping clones with similar characteristics, the genotypes composing a single variety may display different behaviors regarding nutrient uptake and accumulation in their tissues. For the thirteen genotypes that compose the clonal variety 'Vitória Incaper 8142', Covre et al. (2013) reported different nutrient contents in the shoot and roots of seedlings 210 days after staking, a fact that further suggests differences among genotypes in the efficiency with which nutrients are taken up and accumulated.

Monitoring the accumulation of nutrients in fruits during the reproductive period has been one of the main tools used to estimate the crop's nutritional needs and to identify the optimal moments to apply fertilizers. Partelli et al. (2014) studied the nutrient accumulation behavior in fruits of different genotypes of conilon coffee and suggested that those with the shortest maturation cycles are the quickest to accumulate dry matter, $\mathrm{N}, \mathrm{P}, \mathrm{K}, \mathrm{Ca}, \mathrm{Mg}$, and $\mathrm{S}$. These authors also reported that fertilizers must be specifically managed for each genotype.

Given the scarcity of information on the micronutrient contents and rates of uptake in coffee berries, since plants have different aging cycles have a different nutrient absorption curves, the goal of this study was to establish accumulation curves for the micronutrients $\mathrm{B}, \mathrm{Cu}, \mathrm{Fe}, \mathrm{Mn}$, and $\mathrm{Zn}$ in conilon coffee plant fruits with different maturation cycles.

\section{MATERIAL AND METHODS}

The experiment was carried out in Nova Venécia, State of Espírito Santo (ES), Brazil, during the 
reproductive cycle of the 2010/2011 crop year. The area is located at the geographical coordinates $18^{\circ} 43^{\prime} 46^{\prime \prime} \mathrm{S}, 40^{\circ} 23^{\prime} 10^{\prime \prime} \mathrm{W}$, at a mean altitude of $100 \mathrm{~m}$. At the study site, the minimum temperature ranges from 11.8 to $18{ }^{\circ} \mathrm{C}$, and the maximum temperature ranges from 30.7 to $34^{\circ} \mathrm{C}$, with rainfall of approximately 1,200 $\mathrm{mm}$ per year (Incaper, 2012). During the experiment, the crop was duly irrigated, so there was no water deficit.

Coffea canephora var. conilon plants with an age of three years were studied. The plants were grown in full sun at a density of 3,333 plants ha ${ }^{-1}$, spaced at $3 \times 1 \mathrm{~m}$, with four orthotropic stems per plant. The soil was classified as a Latossolo Amarelo Distrófico coeso (Oxisol) (Embrapa, 2013) with clayey texture, rolling terrain, and the following properties in the 0.00-0.20 m layer: $\mathrm{pH}\left(\mathrm{H}_{2} \mathrm{O}\right) 5.41, \mathrm{P} 6.1 \mathrm{mg} \mathrm{dm}^{-3}$, $\mathrm{K} 66 \mathrm{mg} \mathrm{dm}^{-3}, \mathrm{Ca}^{2+} 1.35 \mathrm{cmol}_{\mathrm{c}} \mathrm{dm}^{-3}, \mathrm{Mg}^{2+} 0.78 \mathrm{cmol}_{\mathrm{c}} \mathrm{dm}^{-3}$, $\mathrm{H}+\mathrm{Al} 2 \mathrm{cmol}_{\mathrm{c}} \mathrm{dm}^{-3}, \mathrm{~S}_{-} \mathrm{SO}_{4} 7.0 \mathrm{mg} \mathrm{dm}^{-3}, \mathrm{~B} 0.2 \mathrm{mg} \mathrm{dm}^{-3}$, $\mathrm{Cu} 0.4 \mathrm{mg} \mathrm{dm}^{-3}$, Fe $36.8 \mathrm{mg} \mathrm{dm}^{-3}$, Mn $21.0 \mathrm{mg} \mathrm{dm}^{-3}$, and $\mathrm{Zn} 3.2 \mathrm{mg} \mathrm{dm}^{-3}$, according to Silva (2009).

To fertilize production, $110 \mathrm{~g}$ superphosphate and $80 \mathrm{~g}$ of $20-00-20$ fertilizer were applied, per plant, in November and December 2010, respectively, whereas in March and May 2011, respectively 100 and $120 \mathrm{~g}$ of 20-00-20 fertilizer were applied.

The selected genotypes were, respectively, the $12 \mathrm{~V}, 10 \mathrm{~V}$, and $13 \mathrm{~V}$ clones of conilon Vitória 8142 variety and Ipiranga 501 variety. Four coffee tree genotypes (clones) with different maturation cycles (early, intermediate, late, and super-late) were used. Treatments corresponded to periods in which fruits were gathered to ascertain nutrient accumulation during each genotype's period of fruit formation.

The experimental design was completely randomized with five replications. Initially, plagiotropic branches were marked with the same pattern in 70 random plants of each genotype. The experimental sample consisted of one plant from which a plagiotropic branch was removed every 28 days of the period from flowering to fruit maturation to assess fruit dry matter, as well as the $\mathrm{Fe}, \mathrm{Zn}, \mathrm{Cu}$, $\mathrm{Mn}$, and $\mathrm{B}$ concentration and accumulation in the fruit. The branches had, on average, 30 productive berry clusters.

Sampling began on August 14, 2010, 20 days after anthesis for the early and intermediate genotypes $(12 \mathrm{~V}$ and $10 \mathrm{~V})$ and on September 11, 2010 for the late and super-late genotypes (13 V and Ipiranga 501). Prior to that, 65 uniform plagiotropic branches were randomly marked for each genotype, and five branches were removed/sampled at random every 28 days. Sampling ended on March 6, April 8, May 7, and July 3, 2011 for the early, average, intermediate, and late genotypes, respectively.

Sample fruits were extracted and dried in a forced-air oven at $70{ }^{\circ} \mathrm{C}$ until the fruits reached constant weight; then, their dry matter was determined with a $0.001 \mathrm{~g}$ precision scale. The fruits were ground using a Willey stainless steel mill and sieved through a $0.841 \mathrm{~mm}$ fine mesh to conduct chemical analysis of $\mathrm{Fe}, \mathrm{Zn}, \mathrm{Cu}, \mathrm{Mn}$, and $\mathrm{B}$. The analyses were carried out using the methods described by Silva (2009), in triplicate.

Nutrient accumulation in the berries found on the branches was calculated, based on the dry matter and the concentrations of the respective nutrients. Subsequently, the percentage of accumulation at different times was computed, considering the value from the last batch as $100 \%$, when over $80 \%$ of the fruits on the branches were completely mature.

Data were subjected to regression analysis, and mathematical models were chosen according to the significance of the regression coefficients of the equations and the $F$-test for regression $(p \leq 0.05)$. The best fits were indicated by higher values of the coefficient of determination $\left(\mathrm{R}^{2}\right)$. Statistical analysis was performed using Assistat 7.6 (Silva, 2013). Data plots were created using mean values and their standard deviations.

\section{RESULTS AND DISCUSSION}

Early, intermediate, and late genotypes accumulated the nutrients $\mathrm{Fe}, \mathrm{Cu}$, and $\mathrm{Mn}$ similarly, with 3-parameter sigmoid curves, whereas the super-late genotype accumulated these nutrients exponentially (Figures 1, 2, and 3). The sigmoid curves displayed an initial phase of slower accumulation, followed by a phase of strong intensification (with higher rates) and a phase with lower rates at the end of the cycle of berry formation. In contrast, the exponential increase displayed by super-late genotype suggests lower accumulation rates at the beginning of berry formation and an exponential increase up to the final phase of berry formation, when this rate reached its highest values.

High $\mathrm{Fe}, \mathrm{Cu}$, and $\mathrm{Mn}$ accumulation rates were found in the intermediate phase, starting on the $76^{\text {th }}$ day after anthesis (Figures 1, 2, and 3). All studied genotypes accumulated $\mathrm{Zn}$ following a sigmoid curve, displaying a phase of slow accumulation at the beginning of berry formation, followed by a phase of fast accumulation in the intermediate period of the berry formation/maturation cycle. Despite the nutrient accumulation curves being similar, the beginning of the fast accumulation phase depended on genotype; moreover, the late and super-late genotypes displayed reduced accumulation rates near the end of the cycle, whereas the early and intermediate genotypes displayed high accumulation rates until the fruits were mature (Figure 4). The early, intermediate, and late genotypes accumulated B linearly, 


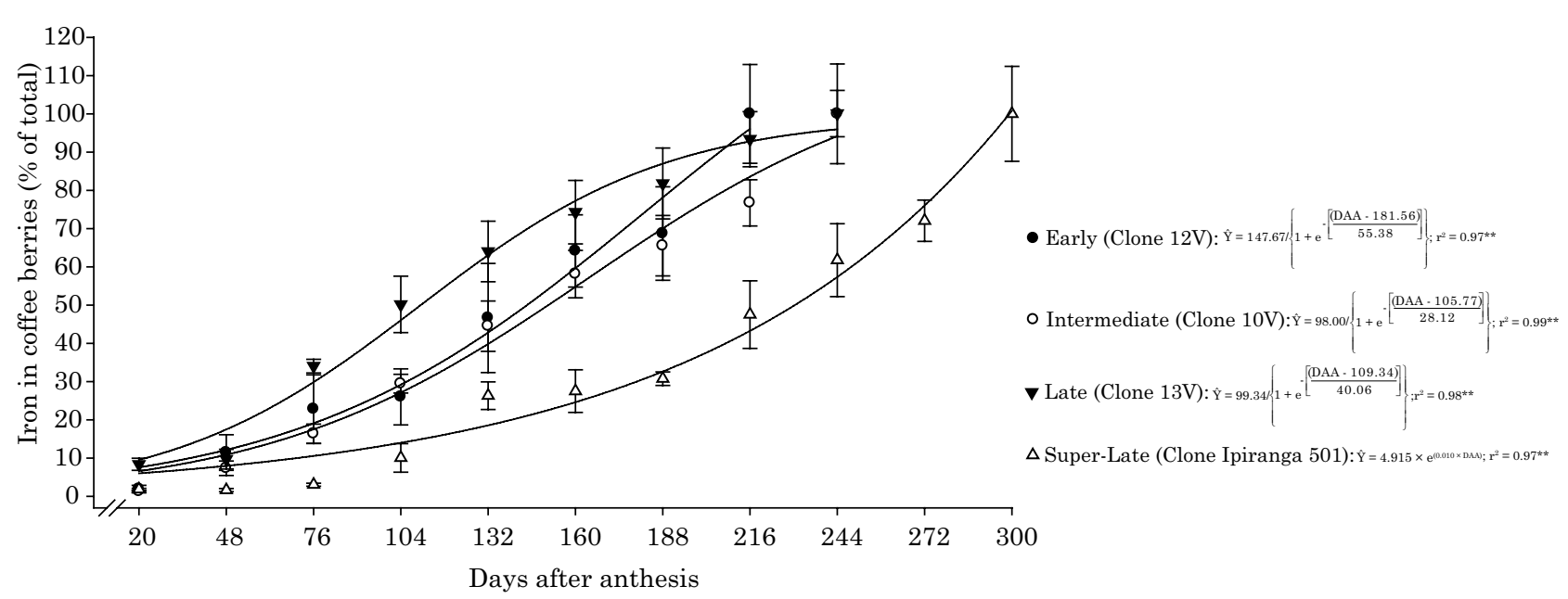

Figure 1. Iron accumulation in berries (as a percentage of total accumulation) of four genotypes (clones) of 'conilon' coffee, from anthesis to fruit maturation. Bars represent standard deviation of the mean. **: significant at $1 \%$.

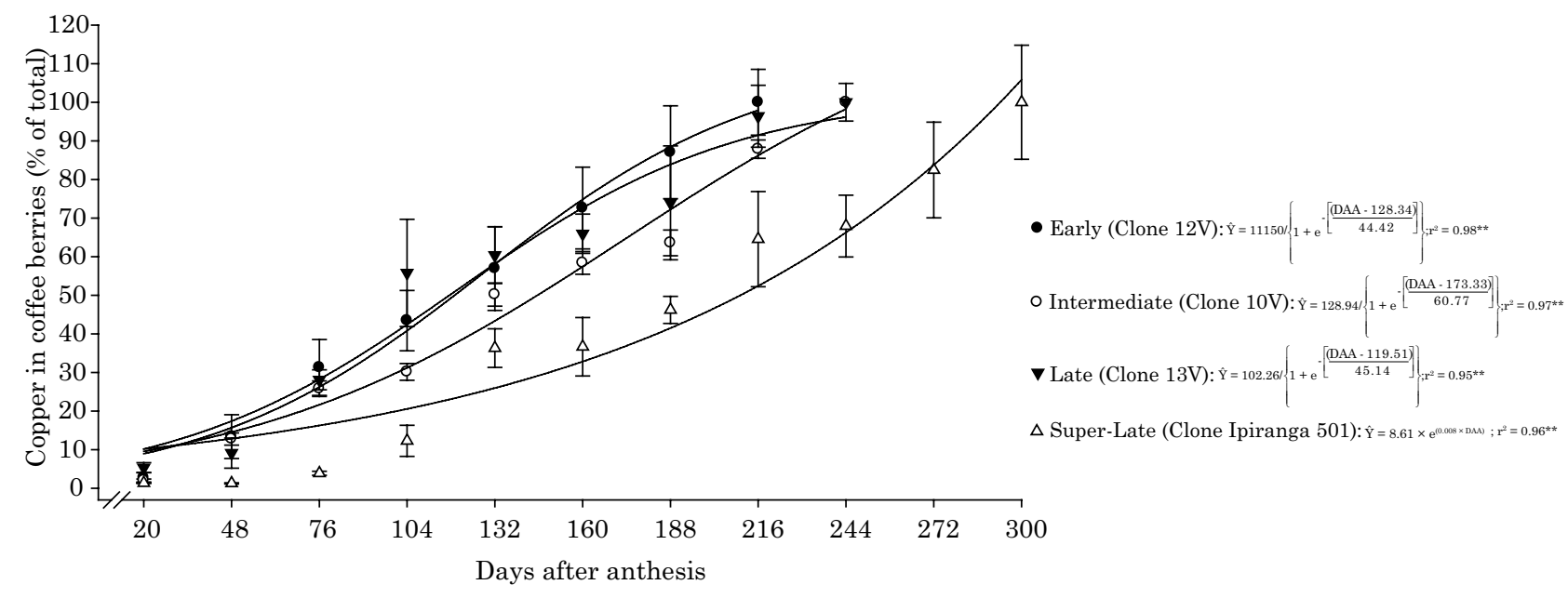

Figure 2. Copper accumulation in berries (as a percentage of total accumulation) of four genotypes (clones) of 'conilon' coffee, from anthesis to fruit maturation. Bars represent standard deviation of the mean. **: significant at $1 \%$.

whereas the super-late genotype accumulated B according to a sigmoid curve (Figure 5). This fact suggests that the genotypes have different needs, requiring different management.

The sigmoidal behaviors displayed by early, intermediate, and late genotypes (Figures 1, 2, and 3) are similar to results reported for arabica coffee plants (Coffea arabica L.) grown at different altitudes (Laviola et al., 2007), i.e., the main commercial species of the Coffea genus show similar behavior. However, the difference between the super-late clone and the other genotypes confirms the great genetic diversity that exists among genotypes of the C. canephora species, as suggested by Souza et al. (2013).
High $\mathrm{Fe}, \mathrm{Cu}$, and $\mathrm{Mn}$ accumulation rates in the intermediate phase, starting on the $76^{\text {th }}$ day after anthesis (Figures 1, 2, and 3), are similar to results reported for C. arabica var. 'Caturra', for which the highest percentages of the accumulation of these nutrients were found between 90 and 120 days after anthesis (Ramírez et al., 2002). This period coincides with fruit's rapid expansion phase (Laviola et al., 2008), a period that requires more water flow to the fruit. The fruit, consequently, receives greater amount of $\mathrm{Fe}, \mathrm{Cu}$, and $\mathrm{Mn}$, which participate as enzyme activators in several metabolic processes. Super-late genotype displayed greater accumulation of $\mathrm{Fe}, \mathrm{Cu}$, and $\mathrm{Mn}$ starting on the $160^{\text {th }}$ day. 


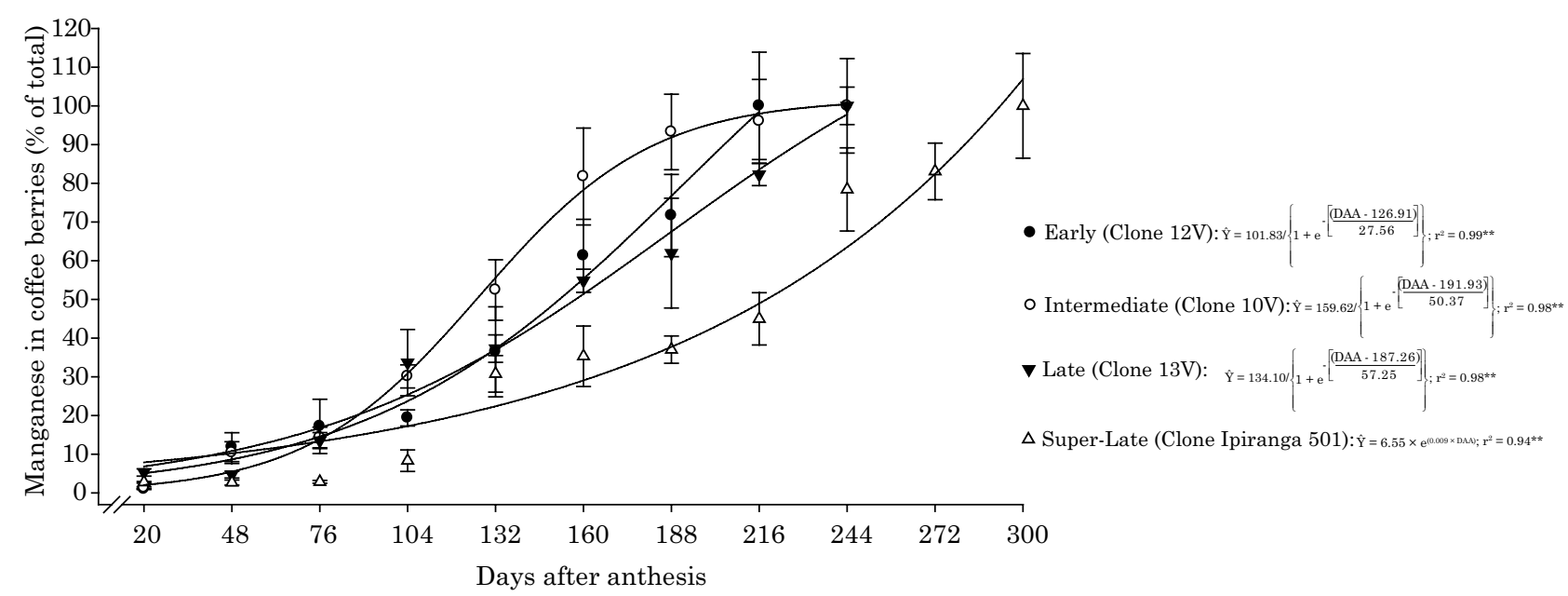

Figure 3. Manganese accumulation in coffee berries (as a percentage of total accumulation) of four genotypes (clones) of 'conilon' coffee, from anthesis to fruit maturation. Bars represent standard deviation of the mean. **: significant at $1 \%$.

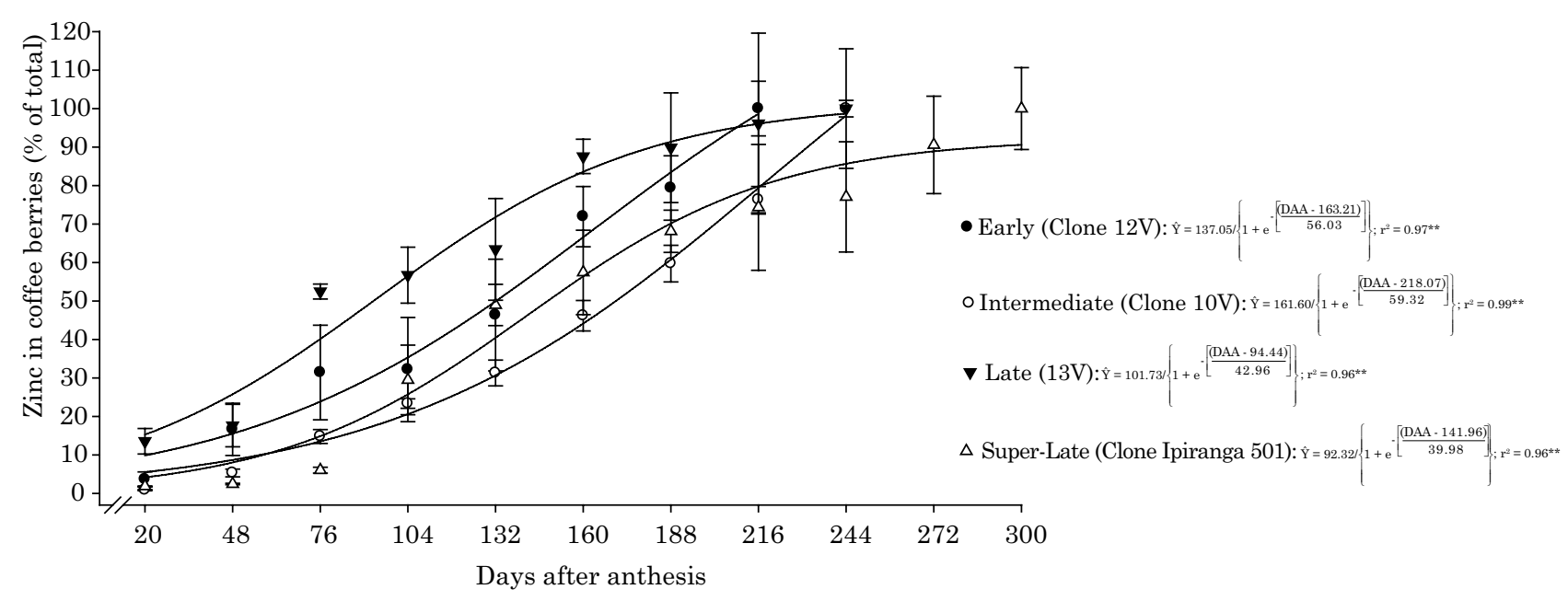

Figure 4. Zinc accumulation in berries (as a percentage of total accumulation) of four genotypes (clones) of 'conilon' coffee, from anthesis to fruit maturation. Bars represent standard deviation of the mean. **: significant at $1 \%$.

The behavior of late and super-late genotypes in regard to $\mathrm{Zn}$ is similar to reported for arabica coffee grown at different altitudes (Laviola et al., 2007), in which a significant increase was observed until the $134^{\text {th }}$ day after anthesis, after which Zn concentration in the berries became stable until the end of the 266-day cycle. Corroborating these results, 'Caturra' arabica coffee grown in Costa Rica accumulated all of its $\mathrm{Zn}$ by the $210^{\text {th }}$ day after anthesis, i.e., there was no increase during the last 30 days of fruit formation, namely from the $210^{\text {th }}$ to the $240^{\text {th }}$ day (Ramírez et al., 2002).

Thus, it is believed that greater $\mathrm{Zn}$ accumulation in the initial/intermediate phase of fruit formation is related to the rapid expansion phase, in which there is intense cellular elongation, an event that depends on auxin (Taiz and Zeiger, 2010). The accumulation patterns of the early and intermediate genotypes suggest that fruit formation phases may overlap or be very brief, presumably due to the short period of time between anthesis and fruit maturation.

The period during which fruits require the most $\mathrm{Zn}$ coincides with the period of vegetative growth, which begins in September and extends to May (Partelli et al., 2010; 2013), and this overlap can lead to competition for the nutrient between the reproductive and vegetative parts. Because of this competition, special attention must be given to this 


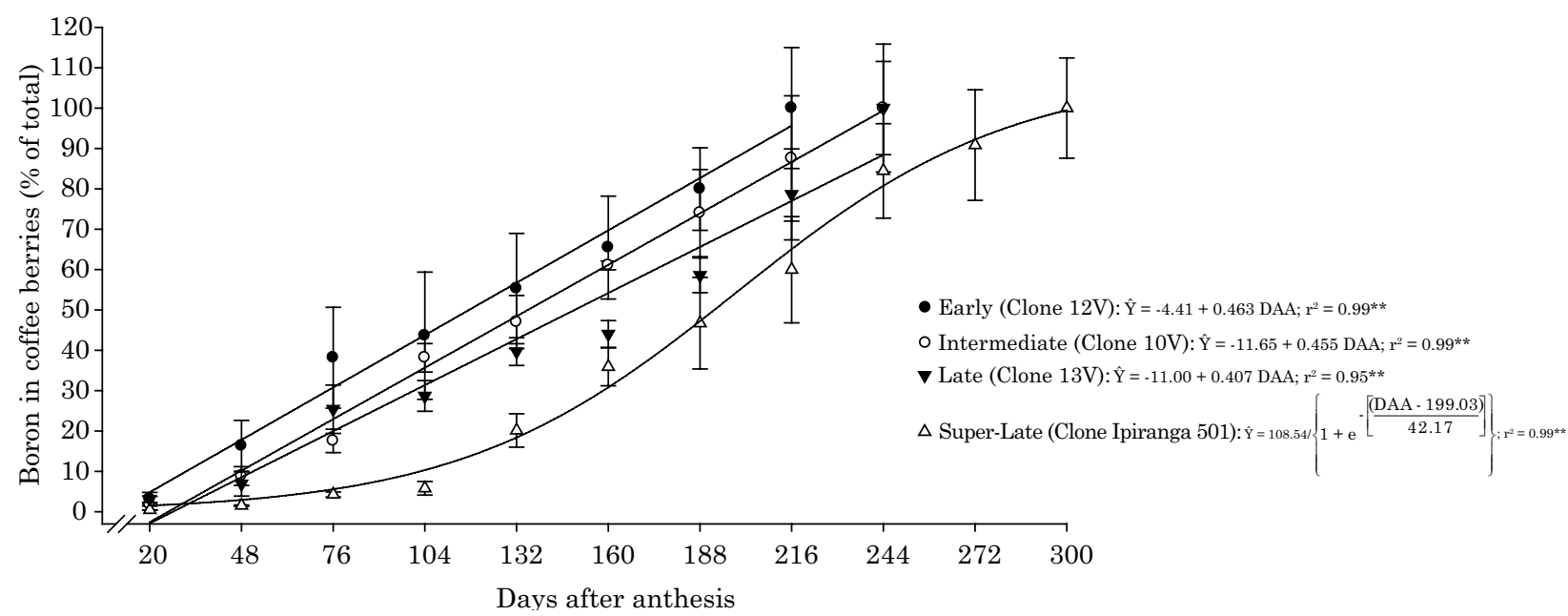

Figure 5. Boron accumulation in berries (as a percentage of total accumulation) of four genotypes (clones) of 'conilon' coffee, from anthesis to fruit maturation. Bars represent standard deviation of the mean. **: significant at $1 \%$.

nutrient at the beginning of the vegetative growth season. Moreover, the soils of the region under study are poor in $\mathrm{Zn}$.

Zinc fertilization management should be studied in more detail given that the beginning of the growth season is the recommended period for phosphate fertilization, in a single application, and this fertilization may lead to $\mathrm{Zn}$ deficiency, due to antagonism between $\mathrm{P}$ and $\mathrm{Zn}$ (Dechen and Nachtigall, 2006). However, there was no evidence of this antagonism in this crop, under the soil and climatic conditions of the present study.

As for B (Figure 5), the results for the early, intermediate, and late genotypes differed from those reported for arabica coffee at different altitudes (Laviola et al., 2007). The super-late genotype displayed a long phase of slow accumulation, initiating a rapid expansion phase only after the $132^{\text {nd }}$ day.

\section{CONCLUSIONS}

The early, intermediate, and late genotypes accumulated $\mathrm{Fe}, \mathrm{Cu}$, and $\mathrm{Mn}$ similarly, with sigmoid curves, whereas the super-late genotype accumulated these nutrients exponentially.

Zinc was accumulated by all the genotypes studied according to the sigmoid curve, though with varying accumulation rates among the genotypes during maturation.

The early, intermediate, and late genotypes showed regular rate of accumulated $B$ whereas the super-late genotype B accumulated in lower rate early in the cycle and accelerated from advancing maturity according to a sigmoid curve.

The maturation cycle of the genotype must be taken into account to apply the correct rate of micronutrient fertilization in coffee plantations.

\section{ACKNOWLEDGMENTS}

The authors thank the Federal University of Espírito Santo for supporting this study, the coffee producer João Batista Marré for providing the area for the study, and Heringer Fertilizers for their support.

\section{REFERENCES}

Bardin-Camparotto L, Camargo MBP, Moraes JFL. Época provável de maturação para diferentes cultivares de café arábica para o Estado de São Paulo. Ci Rural. 2012;42:594-9.

Bragança SM, Carvalho CHS, Fonseca AFA, Ferrão RG. Variedades clonais de café Conilon para o Estado do Espírito Santo. Pesq Agropec Bras. 2001;36:765-70.

Budzinski IGF, Santos TB, Sera T, Pot D, Vieira LGE, Pereira LFP. Expression patterns of three a-expansion isoforms in Coffea arabica during fruit development. Plant Biol. 2011;13:462-71.

Companhia Nacional de Abastecimento - Conab. Acompanhamento da safra Brasileira: Café: Safra 2013, primeira estimativa, janeiro de 2013. [Accessed at 2014 May 01]. Available at: http://www. conab.gov.br/OlalaCMS/uploads/arquivos/14_01_17_09_29_46_ boletim_cafe_-_original_normalizado.pdf.

Covre AM, Partelli FL, Mauri AL, Dias MA. Crescimento e desenvolvimento inicial de genótipos de café Conilon. R Agro@ mb On-line. 2013:7:193-202. 
Davis AP, Tosh J, Ruch N, Fay MF. Growing coffee: Psilanthus (Rubiaceae) subsumed on the basis of molecular and morphological data implications for the size, morphology, distribution and evolutionary history of Coffea. Bot J Linn Soc. 2011;167:357-77.

Dechen AR, Natchtigall GR. Micronutrientes. In: Fernandes MS, editor. Nutrição mineral de plantas. Viçosa, MG: Sociedade Brasileira de Ciência do Solo; 2006. p.327-54.

Empresa Brasileira de Pesquisa Agropecuária - Embrapa. Sistema brasileiro de classificação de solos. $3^{\text {a }}$.ed. Rio de Janeiro: Embrapa Solos; 2013.

Fonseca AFA, Ferrão MAG, Ferrão RG, Verdin-Filho AC, Volpi PS, Zucateli F. 'Conilon Vitória - Incaper 8142': improved Coffea canephora var. kouillou clone cultivar for the state of Espírito Santo. Crop Breed Appl Biot. 2004;4:503-5.

Instituto Capixaba de Pesquisa, Assistência Técnica e Extensão Rural - Incaper. Caracterização: Climáticas dos Municípios: Nova Venécia. [Accessed at 2012 Aug 22]. Available at: http://hidrometeorologia.incaper.es.gov.br/caracterizacao/ novavenecia_carac.php.

Laviola BG, Martinez HEP, Salomão LCC, Cruz CD, Mendonça SM, Rosado L. Acúmulo em frutos e variação na concentração foliar de NPK em cafeeiro cultivado em quatro altitudes. Biosci J. 2008;24:19-31.

Laviola BG, Martinez HEP, Salomão LCC, Cruz CD, Mendonça SM. Acúmulo de nutrientes em frutos de cafeeiro em quatro altitudes de cultivo: cálcio, magnésio e enxofre. $\mathrm{R}$ Bras Ci Solo. 2007;31:1451-62.

Partelli FL, Vieira HD, Silva MG, Ramalho JC. Crescimento vegetativo sazonal em ramos de diferentes idades do cafeeiro conilon. Semina: Ci Agrár. 2010;31:619-26.
Partelli FL, Espindula MC, Marré WB, Vieira HD. Dry matter and macronutrient accumulation in fruits of conilon coffee with different ripening cycles. R Bras Ci Solo. 2014;38:214-22.

Partelli FL, Marré WB, Falqueto AR, Vieira HD, Cavatti PC. Seasonal vegetative growth in genotypes of Coffea canephora, as related to climatic factors. J Agric Sci. 2013:5:108-16.

Petek MR, Sera T, Fonseca ICB. Exigências climáticas para o desenvolvimento e maturação dos frutos de cultivares de Coffea arabica. Bragantia. 2009;68:169-81.

Pezzopane JRM, Pedro Júnior MJ, Thomaziello RA, Camargo MBP. Escala para avaliação de estádios fenológicos do cafeeiro arábica. Bragantia. 2003;62:499-505.

Ramírez F, Bertsch F, Mora L. Consumo de nutrimentos por los frutos y bandolas de café caturra durante un ciclo de desarrollo y maduracion en aquiares, Turrialba, Costa Rica. Agrar. Costarricense. 2002;26:33-42.

Silva FC, organizador. Manual de análise química de solos, plantas e fertilizantes. $2^{\mathrm{a}}$.ed. Brasília, DF: Embrapa; 2009.

Silva FAS. ASSISTAT - Statistical Assistance. version 7.6 beta. Campina Grande: Universidade Federal de Campina Grande; 2013. [Accessed at 2013 May]. Available at: http://www.assistat. com/indexi.html.

Souza FF, Caixeta ET, Ferrao LFV, Pena GF, Sakiyama NS, Zambolim EM, Zambolim L, Cruz CD. Molecular diversity in Coffea canephora germplasm conserved and cultivated in Brazil. Crop Breed Appl Biot. 2013;13:221-7.

Taiz L, Zieger E. Plant Physiology. $5^{\text {th }}$ ed. Plumtree Road, Sunderland, MA: Sinauer Associates, Inc.; 2010. 